\title{
Effect of the Different Soil Types on Chrysanthemum Cut Flower Quality
}

\author{
Herni Shintiavira $^{1 *}$, Endang Sulistyaningsih ${ }^{2}$, Aziz Purwantoro ${ }^{2}$ and Rani Agustina Wulandari ${ }^{2}$ \\ ${ }^{1}$ Indonesian Ornamental Crops Research Institute, Cianjur, West Java, Indonesia; ${ }^{2}$ Department of Agronomy, \\ Faculty of Agriculture, Universitas Gadjah Mada, Yogyakarta, Indonesia
}

${ }^{*}$ Corresponding author: virgro@yahoo.co.id

\begin{abstract}
Cultivating annual crops in the high upland has the potential to increase avalanche and land erosion. Therefore, chrysanthemum extensification from high upland to medium upland can create sustainable agriculture. The differences between high upland and medium upland are microclimate and soil type. Meanwhile, the effect of soil type between the high upland and the medium upland on the chrysanthemum spray type quality is unknown. The study aimed to determine the effect of different soil types on the quality of chrysanthemums when planted in high upland. The study used a split plot design with two factors. The first factor was the type of soil, such as Andosol from the high upland and Latosol from the medium upland. The second factor was the chrysanthemum varieties, such as Yastayuki (white flower), Arosuka Pelangi (yellow flower) and Socakawani (red flower). The results showed that both Andosol and Latosol soil types could produce the same quality of chrysanthemum in all varieties when planted in high upland. The quality aspects of chrysanthemum were the plant height, the stem diameter, the number of flowers and flower color. Consequently, we could extend the cultivation of chrysanthemum in medium upland by using Latosol type soil.
\end{abstract}

Keywords: altitude; color; Chrysanthemum morifolium R; quality; soil type

Cite this as: Shintiavira, H., Sulistyaningsih, E., Purwantoro, A., \& Wulandari, R. A. (2021). Effect of the Different Soil Types on Chrysanthemum Cut Flower Quality. Caraka Tani: Journal of Sustainable Agriculture, 36(2), 329-339. doi: http://dx.doi.org/10.20961/carakatani.v36i2.50123

\section{INTRODUCTION}

One of the government's strategies to increase chrysanthemum production was the extensification of chrysanthemum cultivation from the high upland to the medium upland (Sanjaya et al., 2018). Previously, the chrysanthemum was cultivated in the highlands $700-1200 \mathrm{~m}$ asl (meters above sea levels) to get an environment suitable for its growth and quality (Wasito and Marwoto, 2003). The choice of land expansion to the medium upland is based on considerations as an effort to conserve natural resources in the high upland (Martini, 2014). This is due to agricultural cultivation in the high upland was faced with physical limiting factors such as the high slope of the land, land avalanche and land erosion (Simbolon et al., 2017). Meanwhile, the chrysanthemum is an annual plant, whereas cultivating annual crops in the high upland had the potential to increase avalanche and land erosion (Sutrisno and Heryani, 2013). Therefore, the chrysanthemum extensification from high upland to medium upland can create sustainable agriculture. This is because the cultivation of the chrysanthemum cut flowers as an annual plant in the medium upland reduces the potential of avalanche and land erosion in the high upland. In addition, cultivation in medium upland is closer to the production location and the urban chrysanthemum market as well as efforts to

\footnotetext{
* Received for publication April 6, 2021

Accepted after corrections August 8, 2021
} 
develop agro-tourism areas (Wijayani and Amiaji, 2014).

One of the development areas for chrysanthemum production centers in the high upland is in the Cipanas Sub-district, Cianjur, West Java Province (1100 m asl) (Marwoto et al., 2015). Meanwhile, the chrysanthemum production center in the medium upland is in Samigaluh Sub-district, Kulonprogo, Yogyakarta (400-600 m asl) (Setyono, 2016). However, there were many reports of deterioration in the quality of chrysanthemums when planted in the medium upland such as the decreasing of stem diameter, the decreasing of the blooming flower number, the decreasing of blooming flower diameter, harvesting time and color intensity (Shintiavira et al., 2019). It was known that a decrease in altitude affected changes in the microclimate like an increase in temperature and light intensity. In fact, the quality of chrysanthemum was not only influenced by the microclimate, but also soil type or nutrient factors.

The chrysanthemum cut flower is widely cultivated in the high land where most of the types of soil are Andosols (Fransin et al., 2018). That is in accordance with Nasihin and Qodriyah (2008) in which the type of soil used in chrysanthemum cultivation in high upland in Cipanas Sub-district, West Java Province was also Andosol soil type. Meanwhile, the soil used in chrysanthemum cultivation in medium upland such as Samigaluh Sub-district, Yogyakarta Province was Latosol soil type (Rahmawati et al., 2019). According to Djazuli (2011), Andosol soil from Cipanas had a clay loam texture, moderate acidity level, cation exchange capacity (CEC) and nitrogen total, low phosphorus and potassium level, and high organic matter content. Meanwhile, according to Rahmawati et al. (2019), Latosol soil was dominated by clay, had low drainage, moderate acidity level and CEC, low nitrogen, phosphorus, potassium and organic matter content. The soil characters can be used to know fertilization efficiency (Mulyanto et al., 2015). Therefore, it can be known whether the difference in soil characteristics was a factor that affects the difference in chrysanthemum quality.

However, until now, the effect of soil type between the high upland and the medium upland on the chrysanthemum quality is unknown. This study aimed to determine the effect of different soil types from high upland and medium upland on several varieties of spray type chrysanthemum such as Yastayuki (white flower), Arosuka Pelangi (yellow flower) and Socakawani (red flower). The chrysanthemum 'Yastayuki' and 'Socakawani' are spray type chrysanthemums with secondary branching while 'Arosuka Pelangi' without secondary branching. It is likely that differences in varieties with different growth types will have different responses to the different soil types tested. Therefore, the research was carried out on the cultivation of three varieties of spray type chrysanthemum cut chrysanthemums using two different types of soil, namely Andosol soil from the Cipanas, high upland (1100 m asl) and Latosol soil from the Samigaluh, medium upland (485 $\mathrm{m}$ asl) planted in the high upland. Testing of both types of soil from high land and medium land in the high upland is to minimize the influence of microclimate factors. This is because microclimate in high upland was optimal for the growth of chrysanthemum cut flowers.

\section{MATERIALS AND METHOD}

\section{Planting and preparation materials}

The research was carried out in Cipanas, West Java, Indonesia at an altitude of $1100 \mathrm{~m}$ asl from November 2017 to February 2018. The rooted cuttings in several varieties of spray type chrysanthemum such as Yastayuki, Arosuka Pelangi and Socakawani which had 3-4 perfectly open leaves were used as planting material. The rooted cuttings were planted in beds with a spacing of $10 \mathrm{~cm} \times 10 \mathrm{~cm}$ which were maintained in long-day conditions with additional light from $10.00 \mathrm{pm}-02.00$ am until 30 days after planting (DAP). Previously, the soil was fertilized using $5 \mathrm{~kg} \mathrm{~m}^{-2}$ goat manure, $200 \mathrm{~kg} \mathrm{ha}^{-1}$ Urea (Kujang, Indonesia), $300 \mathrm{~kg} \mathrm{ha}^{-1}$ SP-36 (Petrochemical, Indonesia) and $350 \mathrm{~kg} \mathrm{ha}^{-1} \mathrm{KCL}$ (Kujang, Indonesia). Additional fertilizer in the form of $2 \mathrm{~g} \mathrm{~L}^{-1}$ NPK 16: 16: 16 (Meroke Tetap Jaya, Indonesia), $1 \mathrm{~g} \mathrm{~L}^{-1}$ red $\mathrm{KNO}_{3}$ (El Trovador, Chile), $2 \mathrm{~g} \mathrm{\textrm {L } ^ { - 1 }}$ Gandasil D (Kalatham, Indonesia) given at 0-35 DAP. Furthermore, $2 \mathrm{~g} \mathrm{~L}^{-1} \mathrm{NPK}, 1 \mathrm{~g} \mathrm{~L}^{-1} \mathrm{KNO}_{3}$ white (El Trovador, Santiago, Chile) and $2 \mathrm{~g} \mathrm{~L}^{-1}$ Gandasil B (Kalatham, Indonesia) were added after 35-90 DAP.

\section{Research design}

The study used a split plot design with 3 replications. The main plots were soil types, namely Andosol soil from the Cipanas high 
upland (1100 $\mathrm{m}$ asl) and Latosol from the Samigaluh medium upland $(485 \mathrm{~m}$ asl). The subplots were chrysanthemum varieties, namely Yastayuki, Arosuka Pelangi and Socakawani.

\section{Observation}

\section{Microclimate}

The microclimate observations were the daily average temperature, light intensity and relative humidity. The microclimate variables were observed during plant growth and development. The observation were carried out in five times, every day at $07.00 \mathrm{am}, 09.00 \mathrm{am}, 12.00 \mathrm{pm}, 03.00$ $\mathrm{pm}$ and $05.00 \mathrm{pm}$.

\section{Soil analysis}

The one kilogram soil sample compositely was taken using the diagonal system with five points (Merani et al., 2015). The soil analyses were physical and chemical soil characters. The physical soil characters were volume weight, bulk density and texture category. Meanwhile the chemical properties were the soil $\mathrm{pH}, \mathrm{N}$ total, $\mathrm{P}, \mathrm{K}, \mathrm{Na}$ available and the CEC. Soil analysis was carried out in the Soil Laboratory of Universitas Gadjah Mada, Yogyakarta.

\section{Plant dry weight}

The roots, leaves, stems and flowers were separated. The samples of each plant organ were dried in an oven at $70^{\circ} \mathrm{C}$ for $24-48$ hours until the weight was constant. The plant dry weight was weighed using analytical scales. These variables were observed at harvesting time (92 DAP).

\section{Plant morphology}

(1) The plant height was measured from the base of the stem to the highest leaf formed by the plant, (2) The diameter of the stem was measured on the stem in the middle of the stem height (Viyachaia et al., 2015), (3) The number of flowers in bloom was the number of flowers with stages S5-S6 based (Qi et al., 2016), (4) The diameter of bloom was a measure of the diameter of the flower with stages S5-S6 at harvest, (5) The total number of flowers (buds + blooms) was the number of flower buds in all stages + the number of flowers in bloom calculated $20 \mathrm{~cm}$ from the tip of the plant (Carvalho et al., 2005), (6) The internodes length was measured by divided between plant height and the number of nodes (van der Ploeg et al., 2007), (7) The length of the pedicle was measured from the base of the pedicle to the base of the petals. The length of the pedicle observed was the average length of the pedicle that grew $20 \mathrm{~cm}$ from the end of the plant meristem. These variables were observed at harvesting time (92 DAP).

\section{Flower color}

Flower color was measured using a chromameter. Three flowers per plant were measured by shooting chromameter into the surface of flower petals. The measurement of color by using value $a^{*} \mathrm{~b} *$. The meaning of value a* was redness for $+a^{*}$ and greenish for $-a^{*}$. The meaning of value $b *$ was Yellowish for $+b^{*}$ and bluish for $-b^{*}$ (Nozaki et al., 2006). The visualization of $\mathrm{a} *$ and $\mathrm{b} *$ values using color graphs using the Spectromagic NX software. These variables were observed at harvesting time (92 DAP).

\section{Statistical analysis}

Data on the dry weight of roots, leaves, stems and flowers and plant morphology were analyzed using ANOVA and if there was a significant difference followed by DMRT with $\alpha=0.05$. Statistical analysis using the SAS 9.12 program.

\section{RESULTS AND DISCUSSION}

\section{Observation of microclimates}

The microclimate of the screen house in the Cipanas high land at an altitude of $1100 \mathrm{~m}$ asl from November 2017 to February 2018 measurement showed the average temperature was $24^{\circ} \mathrm{C}$, the light intensity was $17000 \mathrm{~lx}$ and the relative humidity was $80 \%$. The fluctuations in temperature, light intensity and relative humidity were displayed every week (Figures 1, 2 and 3). It was the optimal microclimate for chrysanthemum growth and development. According to Karlsson et al. (1989), the optimal temperature for flower bud initiation of chrysanthemum 'Bright Golden Anne' was $20^{\circ} \mathrm{C}$. Meanwhile, Sumitomo et al. (2008) stated that the optimal temperature for the development of chrysanthemum flowers was $18-23^{\circ} \mathrm{C}$. Furthermore, the temperature above $25^{\circ} \mathrm{C}$ decreased the size of flower diameter of the chrysanthemums and the temperature above $25^{\circ} \mathrm{C}$ decreased the size of the flower diameter and the flower color intensity of chrysanthemum (Nozaki and Fukai, 2008; Nakano et al., 2013). Meanwhile, the optimal light intensity for chrysanthemum growth and development was 12,000-48,0000 lx (Janka et al., 2015). 


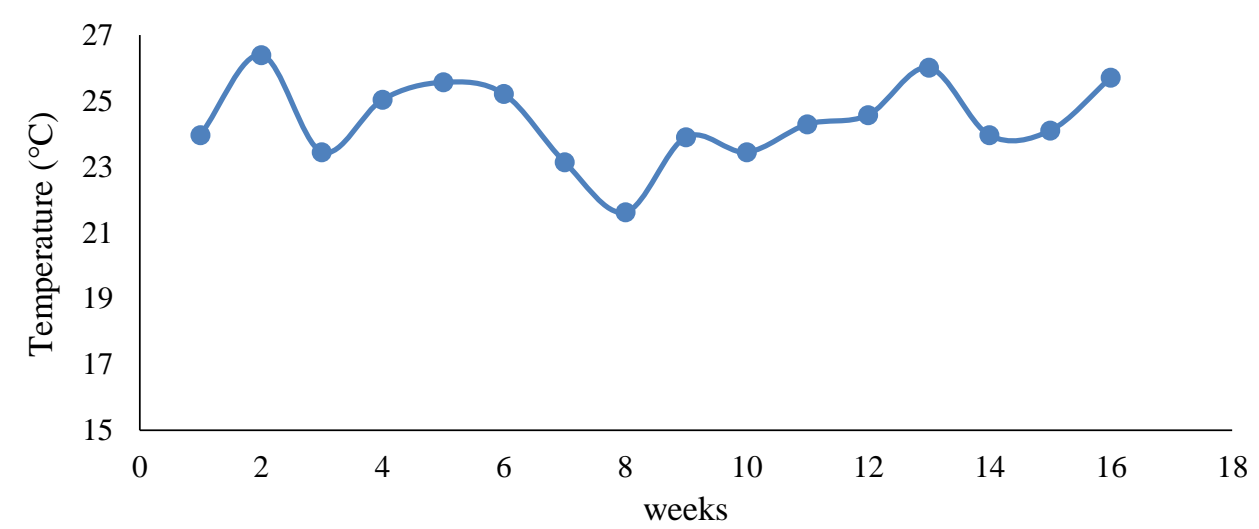

Figure 1. Temperature in Cipanas, Highland, November 2017 to February 2018

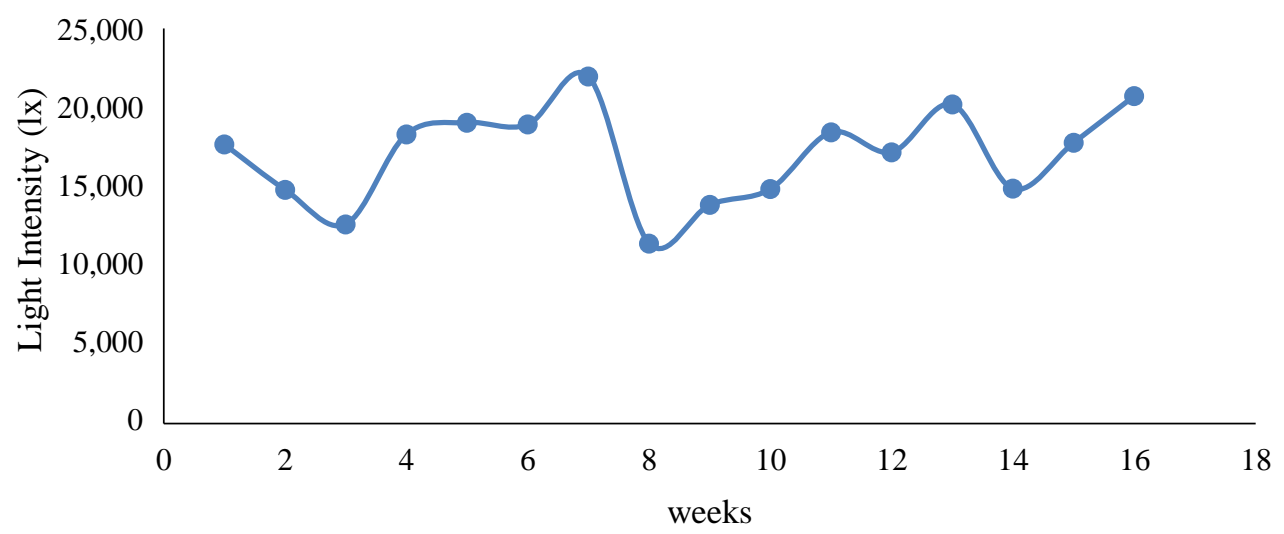

Figure 2. Light intensity in Cipanas, Highland, November 2017 to February 2018

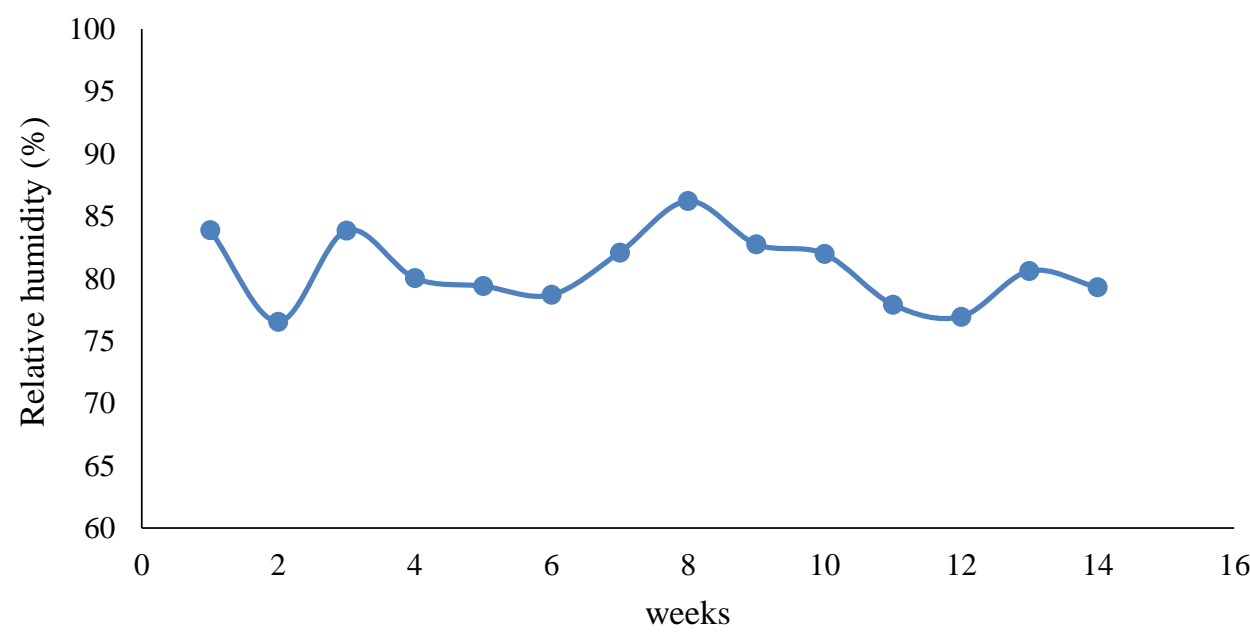

Figure 3. Relative humidity in Cipanas, Highland, November 2017 to February 2018

\section{Soil analysis}

Table 1 showed that the Andosol soil type from Cipanas high upland had a loam texture category while the Latosol soil type from Samigaluh medium upland had a clay texture category. Both Andosol from Cipanas and Latosol from Samigaluh had moderately acid in the $\mathrm{pH}$ range of 5.6-6.5. The soil acidity level was suitable for the media requirements for chrysanthemum plants. Based on soil values, the total $\mathrm{N}$ content of the two media fell into the moderate range $(0.21-0.50 \%)$; $\mathrm{P}$ was available in a high range, (> $3 \mathrm{ppm}$ ); the total available $\mathrm{K}$ was included in the high range, (> $1.0 \mathrm{me}^{\left.100 \mathrm{~g}^{-1}\right)}$ 
and $\mathrm{Na}$ available in the high range (> $1.0 \mathrm{me}$ $100 \mathrm{~g}^{-1}$ ) in both the Andosol and Latosol. The CEC showed the high value in both media. Soil with a high CEC was able to absorb and provide better nutrients. Meanwhile, according to Supriyanto and Purnama (2015), Andosol had varying textures from clay (30-65\%), to coarse clay $(10-20 \%)$. The soil was generally slightly acidic (5.6-6.5). The top layer of organic matter content was medium to high and the lower layer was generally low. The $\mathrm{P}$ and $\mathrm{K}$ content of potency varies, some were moderate to high and some were low to moderate. The soil CEC was mostly moderate to high. Meanwhile, Latosol soil generally provided very low to low fertility potential, where the organic matter content of the upper layer was rather thick $(12-25 \mathrm{~cm})$ and the lower layer gradually decreases to very low to low. The P and K-potential content in the upper layer and the bottom line was almost all very low. The soil CEC was very low. However, Table 1 showed that the Latosol soil from Samigaluh used in the study contains higher N, P, K because it was soil taken from the former chrysanthemum planting. It might be soil cultivation, the addition of organic matter and previous fertilization that affected the increase in soil fertility. According to $\mathrm{Ji}$ et al. (2017), the addition of organic matter was able to affect the character of the soil, thus it increased the absorption of soil nutrients by roots of chrysanthemums.

Table 1. Analysis of Andosol soil from Cipanas and Latosol soil from Samigaluh

\begin{tabular}{|c|c|c|c|c|c|}
\hline \multirow[b]{2}{*}{ Variables } & \multirow[b]{2}{*}{ Unit } & \multicolumn{4}{|c|}{ Results } \\
\hline & & $\begin{array}{l}\text { Soil from } \\
\text { highlands } \\
\text { (Andosol) }\end{array}$ & Classification & $\begin{array}{c}\text { Soil from } \\
\text { medium land } \\
\text { (Latosol) }\end{array}$ & Classification \\
\hline Soil physical characters & & & & & \\
\hline Bulk density & $\mathrm{g} \mathrm{cm}^{-3}$ & 1.98 & & 1.99 & \\
\hline Clay & $\%$ & 16.94 & & 58.89 & \\
\hline Silt & $\%$ & 33.22 & & 20.96 & \\
\hline Sand & $\%$ & 49.84 & & 20.15 & \\
\hline Texture category & & Loam & & Clay & \\
\hline $\begin{array}{l}\text { Soil chemical characters } \\
\mathrm{pH}(1: 5)\end{array}$ & & & & & \\
\hline - $\mathrm{H}_{2} \mathrm{O}$ & & 5.65 & moderately & 5.29 & moderately \\
\hline - $\mathrm{KCl}$ & & 6.73 & acid & 5.84 & acid \\
\hline $\mathrm{N}$ total & $\%$ & 0.42 & medium & 0.24 & medium \\
\hline $\mathrm{P}$ available & ppm & 80.60 & very high & 44.79 & very high \\
\hline $\mathrm{K}$ available & me $100 \mathrm{~g}^{-1}$ & 1.68 & high & 3.09 & high \\
\hline $\mathrm{Na}$ available & me $100 \mathrm{~g}^{-1}$ & 2.95 & high & 2.06 & high \\
\hline Cation exchange capacity & me $100 \mathrm{~g}^{-1}$ & 31.56 & high & 26.89 & high \\
\hline
\end{tabular}

\section{Plant dry weight}

The loamy texture was crumbly, moist and able to bind water and nutrients. While the clay texture had a solid nature when it was dry and slippery when it was wet but can hold water and nutrients (Oyinlola and Jinadu, 2012). There was no interaction between soil types and varieties. Furthermore, there was no difference in dry weight of root, stem, leaf and flower in every variety (Table 2). However, the chrysanthemum 'Socakawani' produced the highest biomass. According to Tracy et al. (2013), the roots could grow in both soil textures, but more energy was used to form roots in the clay soil, thereby reducing plant height growth when compared to loamy textured soils. It might be the soil texture affected early growth in the chrysanthemum. In addition, the Andosol and Latosol soils had the same classification in $\mathrm{N}, \mathrm{P}, \mathrm{K}, \mathrm{Na}$ available and CEC (Table 1). This affected the same ability of each variety in the absorption of nutrients for the allocation of plant dry matter. According to Azeezahmed et al. (2016), the higher concentrations of $\mathrm{N}$ and $\mathrm{K}$ in the nutrient solution improved the quality of morphology variables. Application of $250 \mathrm{mg} \mathrm{L}^{-1}$ Nitrogen and 200 $\mathrm{mg} \mathrm{L}^{-1}$ potassium at vegetative phase and 200 $\mathrm{mg} \mathrm{L}^{-1}$ nitrogen and $260 \mathrm{mg} \mathrm{L}^{-1}$ potassium at 
generative phase resulted optimum for growth and flowering chrysanthemum. Satar et al. (2016) stated that the increase in the number of flowers per plant was due to higher levels and balanced application of nitrogen and phosphorus, which would have increased the primary branches and gave more flowers and flower yield. Potassium was a constituent of many energy-rich compounds in the plants and also involved in active root growth and helps in the uptake of other nutrients resulted in the increased number of chrysanthemum flowers (Nikam et al., 2018).

Table 2. Dry weight of root, stem, leaf and flower chrysanthemum

\begin{tabular}{|c|c|c|c|c|c|}
\hline \multirow{2}{*}{ Variables } & \multirow{2}{*}{ Soil type } & \multicolumn{3}{|c|}{ Varieties } & \multirow{2}{*}{ Average } \\
\hline & & Yastayuki & Arosuka Pelangi & Socakawani & \\
\hline \multirow[t]{2}{*}{ Dry weight of root (g) } & Andosol & 0.61 & 0.66 & 0.91 & $0.70 \mathrm{a}$ \\
\hline & Latosol & 0.59 & 0.65 & 0.92 & $0.74 \mathrm{a}$ \\
\hline $\mathrm{cv}=17.86 \%$ & Average & $0.63 b$ & $0.63 b$ & $0.92 \mathrm{a}$ & $(-)$ \\
\hline \multirow[t]{2}{*}{ Dry weight of stem $(\mathrm{g})$} & Andosol & 8.51 & 9.17 & 14.94 & $10.87 \mathrm{a}$ \\
\hline & Latosol & 8.58 & 10.40 & 15.76 & $11.58 \mathrm{a}$ \\
\hline $\mathrm{cv}=15.37 \%$ & average & $8.87 \mathrm{~b}$ & $9.46 \mathrm{~b}$ & $15.35 \mathrm{a}$ & $(-)$ \\
\hline \multirow[t]{2}{*}{ Dry weight of leaf (g) } & Andosol & 4.11 & 3.21 & 6.76 & $4.69 a$ \\
\hline & Latosol & 5.76 & 3.56 & 6.28 & $5.20 \mathrm{a}$ \\
\hline $\mathrm{cv}=18.66 \%$ & average & $4.94 \mathrm{~b}$ & $3.38 \mathrm{c}$ & $6.52 \mathrm{a}$ & $(-)$ \\
\hline \multirow[t]{2}{*}{ Dry weight of flower (g) } & Andosol & 2.31 & 1.82 & 3.97 & $2.70 \mathrm{a}$ \\
\hline & Latosol & 2.32 & 1.96 & 3.56 & $2.61 \mathrm{a}$ \\
\hline $\mathrm{cv}=9.51 \%$ & Average & $2.31 \mathrm{~b}$ & $1.89 \mathrm{c}$ & $3.76 \mathrm{a}$ & $(-)$ \\
\hline
\end{tabular}

Notes: CV was coefficient variable. The means with the same letters are not significantly different based on DMRT, $\alpha=0.05$. However, $(+)$ sign showed there was an interaction between the soil types and varieties while (-) sign means there was none

\section{The plant morphological quality}

The decrease in the growth rate of plant height did not affect the formation of the number of flower buds produced. The same value of CEC and fertility in high land soil and medium land soil impacted the absorption of the nutrients by the roots for the formation of the same flower buds. Based on the ANOVA, there was no significant difference between chrysanthemum planted on soil types with loamy and clay textures in all morphological variables. The average height of the chrysanthemum planted in loam texture was $104.31 \mathrm{~cm}$ with the nodes were 29.60 , while in clay texture was $100.14 \mathrm{~cm}$, with the nodes were 28.09. The formation of the same number of flowers between the chrysanthemums planted in the land from Cipanas (loamy soil) and Samigaluh (clay texture) had an impact on the length of the pedicels and the same flower diameter (Table 3). From the growth and quality of chrysanthemum planted on the two types of soil, the percentage of quality A was not significantly different, around 95.56$97.77 \%$.

Based on quality class A on the Indonesia National Standard of chrysanthemum, the plant height was more than $76 \mathrm{~cm}$, the stem diameter was $4.1-5 \mathrm{~mm}$, the number of blooming flowers was more than 6 and the blooming diameter for spray type chrysanthemum was $4 \mathrm{~cm}$ (BSN, 1998). These results indicated that the soil differences in the high and medium land did not affect the quality of chrysanthemums. This was in line with the statement that the Andosol and Latosol soils that were used in the medium land did not affect the plant height, stem diameter and yield of tomatoes (Sutapradja, 2008). These results could evaluate the performance of different varieties under different soil types. For general, the best variety based on plant morphological quality was Socakawani.

\section{Color of chrysanthemum flowers}

The flower color was one of the most important quality aspects in ornamental plants (Puangkrit et al., 2018). Flower color depends on the accumulation of secondary compounds, including flavonoids, carotenoids, or betalains. Anthocyanins, members of the flavonoid were mainly involved in the color development of a wide range of orange to red and purple to blue flowers. Carotenoids were natural pigments 
that constitute the yellow or orange flowers especially in chrysanthemum (Park et al., 2015). The difference in soil texture also did not affect the color of the flowers as indicated by the chroma values a $*$ (which indicated a reddish value) and $\mathrm{b} *$ (which indicated a yellowish value). It was not significantly different for each variety. If the flower color was seen based on the CIELAB chart (Figure 4), it showed that the color of each flower planted with soil types Andosol from highland and Latosol from medium land had a close range. Flower color was influenced by physical factors such as temperature, light and chemical factors such as $\mathrm{pH}$ of the planting media and nutrition (Zhao and Tao, 2015).

Table 3. The plant morphological quality of chrysanthemum cultivated in different soil type

\begin{tabular}{|c|c|c|c|c|c|}
\hline \multirow{2}{*}{ Variables } & \multirow{2}{*}{ Soil type } & \multicolumn{3}{|c|}{ Varieties } & \multirow{2}{*}{ average } \\
\hline & & Yastayuki & Arosuka Pelangi & Socakawani & \\
\hline \multirow[t]{2}{*}{ Plant height $(\mathrm{cm})$} & Andosol & 105.46 & 104.37 & 103.10 & $104.31 \mathrm{a}$ \\
\hline & Latosol & 99.97 & 100.12 & 100.34 & $100.14 \mathrm{a}$ \\
\hline $\mathrm{cv}=3.48 \%$ & Average & $102.71 \mathrm{a}$ & $102.25 \mathrm{a}$ & $101.72 \mathrm{a}$ & $(-)$ \\
\hline \multirow[t]{2}{*}{ Stem diameter $(\mathrm{mm})$} & Andosol & 6.05 & 6.27 & 8.09 & $6.89 \mathrm{a}$ \\
\hline & Latosol & 6.39 & 6.25 & 8.21 & $6.95 \mathrm{a}$ \\
\hline $\mathrm{cv}=6.63 \%$ & Average & $6.22 b$ & $6.26 \mathrm{~b}$ & $8.15 \mathrm{a}$ & $(-)$ \\
\hline \multirow[t]{2}{*}{ Number of blooming flower } & Andosol & 8.66 & 9.55 & 9.22 & $9.14 \mathrm{a}$ \\
\hline & Latosol & 9.83 & 8.61 & 9.09 & $9.17 \mathrm{a}$ \\
\hline $\mathrm{cv}=3.48 \%$ & Average & $9.24 a$ & $9.08 \mathrm{a}$ & $9.16 \mathrm{a}$ & $(-)$ \\
\hline \multirow[t]{2}{*}{ Flower diameter $(\mathrm{cm})$} & Andosol & 6.26 & 5.18 & 5.60 & $5.68 \mathrm{a}$ \\
\hline & Latosol & 6.50 & 5.24 & 5.33 & $5.69 \mathrm{a}$ \\
\hline $\mathrm{cv}=6.28 \%$ & Average & $6.38 \mathrm{a}$ & $5.21 \mathrm{~b}$ & $5.46 \mathrm{a}$ & $(-)$ \\
\hline \multirow[t]{2}{*}{ Total number of flowers } & Andosol & 11.13 & 9.66 & 12.92 & $11.24 \mathrm{a}$ \\
\hline & Latosol & 11.53 & 9.05 & 12.87 & $11.15 \mathrm{a}$ \\
\hline $\mathrm{cv}=11.71 \%$ & Average & $11.11 \mathrm{a}$ & $9.36 \mathrm{~b}$ & $12.89 \mathrm{a}$ & $(-)$ \\
\hline \multirow[t]{2}{*}{ Length of internode $(\mathrm{cm})$} & Andosol & 3.01 & 3.07 & 3.09 & $3.06 \mathrm{a}$ \\
\hline & Latosol & 3.10 & 3.02 & 3.12 & $3.08 \mathrm{a}$ \\
\hline $\mathrm{cv}=3.72 \%$ & Average & $3.05 \mathrm{a}$ & $3.04 \mathrm{a}$ & $3.10 \mathrm{a}$ & $(-)$ \\
\hline \multirow[t]{2}{*}{ Pedicle $(\mathrm{cm})$} & Andosol & 12.88 & 11.82 & 16.77 & $13.82 \mathrm{a}$ \\
\hline & Latosol & 13.52 & 11.99 & 16.05 & $13.85 \mathrm{a}$ \\
\hline $\mathrm{cv}=6.99 \%$ & Average & $13.20 \mathrm{~b}$ & $11.90 \mathrm{c}$ & $16.41 \mathrm{a}$ & $(-)$ \\
\hline
\end{tabular}

Notes: CV was coefficient variable. The means with the same letters are not significantly different based on DMRT, $\alpha=0.05$. However, $(+)$ sign showed there was an interaction between soil types and varieties while (-) sign means there was none

The same cultivation locations showed no differences in temperature and light, while the soil types Andosol from high land and Latosol from medium land also showed the same $\mathrm{pH}$ and nutrient values (total Nitrogen, available Phosphorus and Potassium) (Table 1). Besides nitrogen and phosphorous, the potassium affected growth and flower color (Ahmed et al., 2017). There was a gradual increase in the anthocyanin content up to $150 \mathrm{~kg} \mathrm{ha}^{-1}$ urea in petal flowers of chrysanthemum 'Angel' (Mehrabani, 2017). There was a gradual increase in the carotenoids content with levels of potassium applied from 0 to $240 \mathrm{~kg} \mathrm{ha}^{-1}$ in petal flowers of African Marigolds (Sanghamitra et al., 2015).

Based on a series of research results showed that both the soil types Andosol and Latosol could be used for chrysanthemum cultivation. It means, that the fundamental difference between the high upland and medium upland was their microclimate. It might be, there was another factor that could reduce the quality of chrysanthemums when planted in the medium upland. Therefore, the extension of chrysanthemums in the medium upland could be done by paying attention to the microclimate aspect by adding environmental modifications. 
$b^{+}$

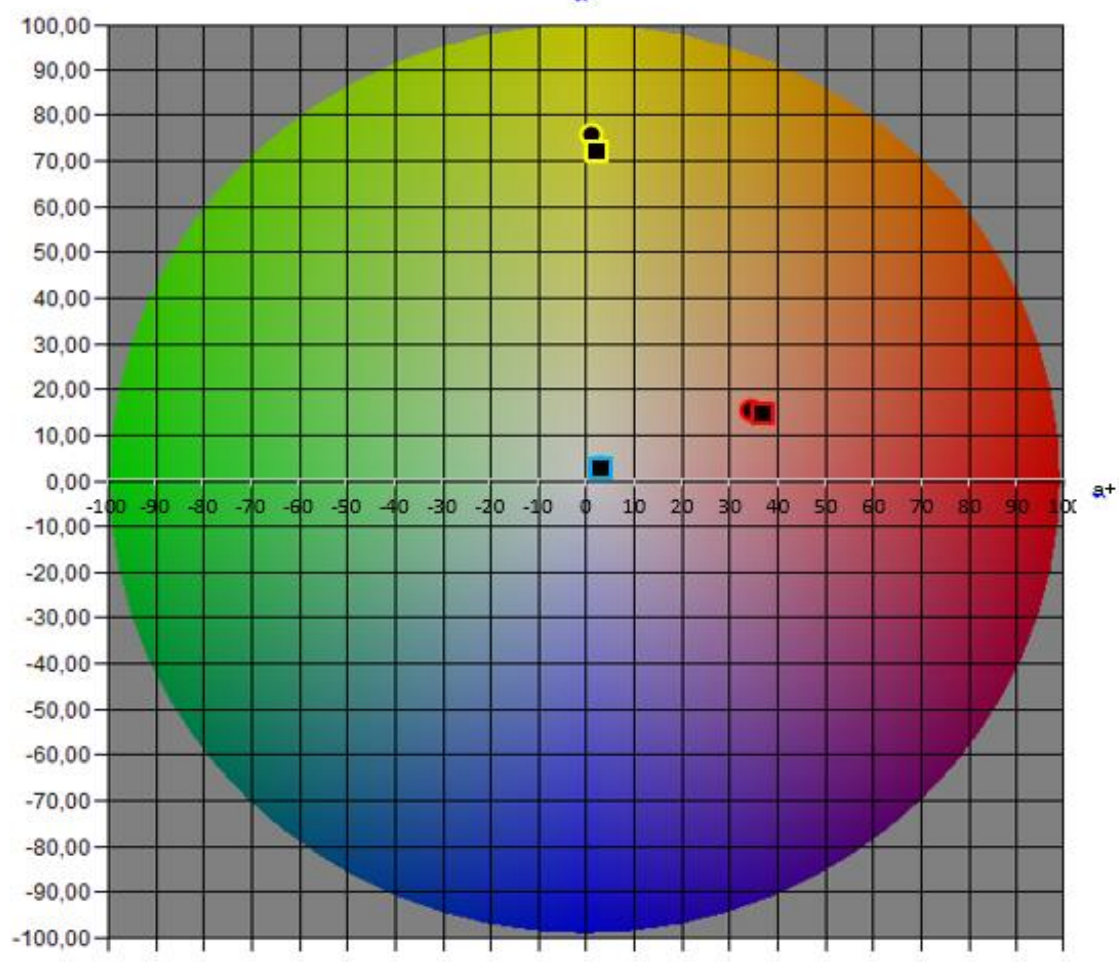

Figure 4. The color range based on $\mathrm{a} *$ and $\mathrm{b} *$ value using color graphs using the Spectromagic $N X$ software. The sign was Andosol soil type from Cipanas, the $\mathbf{D}_{\text {was Latosol soil }}$ type from Samigaluh. The line _ for Yastayuki, for Arosuka Pelangi, _ for Socakawani

\section{CONCLUSIONS}

The loamy clay soil and the clay soil did not affect the morphological quality and color of chrysanthemums in the Yastayuki, Arosuka Pelangi and Socakawani varieties. The results that both Andosol and Latosol soil types could produce the same quality of chrysanthemum in all varieties when planted in high upland. The quality aspects of the chrysanthemum were the plant height, the stem diameter, the number of flowers and flower color. Consequently, we could extend the cultivation of chrysanthemum in medium upland by using Latosol type soil. Therefore, the extension of chrysanthemums in the medium upland could be done by paying attention to the microclimate aspect by adding environmental modifications.

\section{ACKNOWLEDGEMENT}

The authors acknowledge for Indonesian Agency for Agricultural Research and Development (IARRD) scholarship of their support and fund grant in 2018.

\section{REFERENCES}

Ahmed, R., Hussain, M. J., Ahmed, S., Karim, M. R., \& Siddiky, M. A. (2017). Effect of $\mathrm{N}, \mathrm{P}$ and $\mathrm{K}$ fertilizer on the flower yield of Chrysanthemum. The Agriculturists, 15(1), 58-67. https://doi.org/10.3329/agric. v15i1.33429

Azeezahmed, S. K., Dubey, R. K., Kukal, S. S., \& Sethi, V. P. (2016). Effect of different nitrogen-potassium concentrations on growth and flowering of chrysanthemum in a drip hydroponic system. Journal of Plant Nutrition, 39(13), 1891-1898. https://doi.org/10.1080/ 01904167.2016.1187749

BSN. (1998). SNI Bunga Krisan Potong Segar. SNI01-4478-1998. Retrieved from https:// fdokumen.com/document/standar-nasional-in donesia-diameter-tangkai-bunga-adalah-garistengah-tangkai.html

Carvalho, S. M., Abi-Tarabay, H., \& Heuvelink, E. (2005). Temperature affects chrysanthemum flower characteristic 
differently during three phases of cultivation period. The Journal of Horticultural Science and Biotechnology, 80(2), 209-216. https:// doi.org/10.1080/14620316.2005.11511919

Djazuli, M. (2011). Pengaruh pupuk P dan mikoriza terhadap produksi dan mutu simplisia purwoceng. Buletin Penelitian Tanaman Rempah dan Obat, 22(2), 147156. Retrieved from http://ejurnal.litbang. pertanian.go.id/index.php/bultro/article/view/ 1852

Fransin, Santoso, M., \& Aini, N. (2018). Improving phosphorus uptake of chrysanthemum (Chrysantemum morifolium R.) with application of PGPR (plant growth promoting rhizobacteria) and AM (arbuskular mycorrhizal) on Andosol. Jurnal Produksi Tanaman, 6(8), 1756-1762. Retrieved from http://protan.studentjournal. ub.ac.id/index.php/protan/article/viewFile/83 $7 / 860$

Janka, E., Körner, O., Rosenqvist, E., \& Ottosen, C. O. (2015). Using the quantum yields of photosystem II and the rate of net photosynthesis to monitor high irradiance and temperature stress in chrysanthemum (Dendranthema grandiflora). Plant Physiology and Biochemistry, 90, 14-22. https://doi.org/10.1016/j.plaphy.2015.02.019

Ji, R., Dong, G., Shi, W., \& Min, J. (2017). Effects of liquid organic fertilizers on plant growth and rhizosphere soil characteristics of chrysanthemum. Sustainability, 9(841), 1-16. https://doi.org/10.3390/su9050841

Karlsson, M. G., Heins, R. D., Erwin, J. E., \& Berghage, R. D. (1989). Development rate during four phases of chrysanthemum growth as determined by preceding and prevailing temperatures. Journal of the American Society for Horticultural Science, 114(2), 234-240. Retrieved from https://www.researchgate.net/ publication/291812678_Development_rate_d uring_four_phases_of_chrysanthemum_growt h_as_determined_by_preceding_and_prevaili ng_temperatures

Martini, T. (2014). Kajian pengendalian penyakit karat (Puccinia horiana) pada tanaman krisan berdasarkan prinsip epidemi [Dissertation]. Yogyakarta: Universitas Gadjah Mada. Retrieved from http://etd.repository.ugm.ac.

\section{id/home/detail_pencarian/76301}

Marwoto, B., Sanjaya, L., \& Soehendi, R. (2015). Inovasi teknologi tanaman hias krisan pendongkrak kesejahteraan petani florikultura nasional. Inovasi Hortikultura, 8(2), 184-201. Retrieved from https://hortikultura.litbang. pertanian.go.id/Buku_Inovasi/184-201.Budi marwoto\%20krisan.pdf

Mehrabani, L. V. (2017). The effects of nitrogen fertilizer sources on yield and some quality attributes of Chrysanthemum morifulium L. Journal of Ornamental Plants, 7(4), 229-236. Retrieved from http://jornamental.iaurasht.ac. ir/article_537040.html

Merani, N. N., Tola, K. S. K., \& Kubangun, S. H. (2015). Status kesuburan tanah pada lahan pokem (Setaria italic L., Beauv) di kampung Bawei Distrik Numfor Timur. Jurnal Agrotek, 4(7), 44-56. Retrieved from http://journal. faperta.unipa.ac.id/index.php/agrotek/article/v iew/134

Mulyanto, B. S., Supriyadi, S., \& Purnomo, D. (2015). Analisis tanah untuk rekomendasi pemupukan pada budidaya jagung, padi dan ketela pohon. Caraka Tani: Journal of Sustainable Agriculture, 30(2), 91-96. https://doi.org/10.20961/carakatani.v30i2.119 24

Nakano, Y., Higuchi, Y., Sumitomo, K., \& Hisamatsu, T. (2013). Flowering retardation by high temperature in chrysanthemums: involvement of FLOWERING LOCUS T-like 3 gene repression. Journal of Experimental Botany, 64(4), 909-920. https://doi.org/ $10.1093 / \mathrm{jxb} / \mathrm{ers} 370$

Nasihin, Y., \& Qodriyah, L. (2008). Teknik perlakuan periode hari panjang dan pemberian GA3 terhadap produksi bunga potong krisan. Buletin Teknik Pertanian, 13(2), 55-58. Retrieved from http://203.190.37.42/publi kasi/bt132084.pdf

Nikam, B. S., Badge, S. A., \& Pawar, A. R. (2018). Growth and seed yield of annual chrysanthemum as influenced by different levels of nitrogen and potassium. International Journal of Current Microbiology and Applied Sciences, 7(9), 563-568. Retrieved from https://www.ijcmas.com/7-9-2018/B.S.\%20Ni kam,\%20et\%20al.pdf 
Nozaki, K., \& Fukai, S. (2008). Effects of high temperature on floral development and flowering in spray chrysanthemum. Journal of Applied Horticulture, 10(1), 8-14. https:// doi.org/10.37855/jah.2008.v10i01.02

Nozaki, K., Takamura, T., \& Fukai, S. (2006). Effects of high temperature on flower colour and anthocyanin content in pink flower genotypes of greenhouse chrysanthemum (Chrysanthemum morifolium Ramat.). Journal of Horticultural Science and Biotechnology, 81(4), 728-734. https://doi.org/10.1080/1462 0316.2006 .11512130

Oyinlola, E. Y., \& Jinadu, S. (2012). Growth, yield and nutrient concentrations of tomato as affected by soil textures and nitrogen. Asian Journal of Agricultural Research, 6(1), 39-45. https://doi.org/10.3923/ajar.2012.39.45

Park, C. H., Chae, S. C., Park, S., Kim, J. K., Kim, Y. J., Chung, S. O., Arasu, M. V., Aldhabi, N. A., \& Park, S. U. (2015). Anthocyanin and carotenoid contents in different cultivars of Chrysanthemum (Dendranthema grandiflorum Ramat.) flower. Molecules, 20(6), 11090-11102. https://doi.org/10.3390/molecules200611090

Puangkrit, T., Narumi-Kawasaki, T., Takamura, T., \& Fukai, S. (2018). Inflorescence developmental stage-specific high temperature effect on petal pigmentation in chrysanthemum. Environmental Control in Biology, 56(3), 99-106. https://doi.org/ 10.2525/ecb.56.99

Qi, S., Yang, L., Wen, X., Hong, Y., Song, X., Zhang, M., \& Dai, S. (2016). Reference gene selection for RT-qPCR analysis of flower development in Chrysanthemum morifolium and Chrysanthemum lavandulifolium. Frontiers in Plant Science, 7, 287. https:// doi.org/10.3389/fpls.2016.00287

Rahmawati, I., Sulistyaningsih, E., \& Purwantoro, A. (2019). The growth and flowering of potted chrysanthemum (Chrysanthemum morifolium Ramat) on types of organic media and watering frequent. Ilmu Pertanian (Agricultural Science), 4(2), 59-64. https:// doi.org/10.22146/ipas.42163

Sanghamitra, M., Bhaskar, V. V., Rao, A. V. D. D., \& Subbaramamma, P. (2015). Effect of different source and levels of potassium on yield and carotenoids content of African Marigold (Tagetes erecta Linn.) cv.'Maxima Yellow'. Plant Archives, 15(2), 633-636. Retrieved from http://plantarchives.org/pdf \%2015-2/633-636\%20(3114).pdf

Sanjaya, L., Marwoto, B., Budiarto, K., \& Fibrianty, E. (2018). The evaluation of chrysanthemum clones under low elevation. AGRIVITA, 40(2), 193-201. https://doi.org/ 10.17503/agrivita.v40i0.1753

Satar, V. P., Panchbhai, D. M., Badge, S., \& Shivankar, S. (2016). Growth and flower yield of annual chrysanthemum as influenced by nitrogen and phosphorus levels. Plant Archives, 16(2), 523-526. Retrieved from http://plantarchives.org/PDF\%20162/523-526 .pdf

Setyono, B. (2016). Prospek pengembangan agribisnis bunga potong krisan di Kecamatan Samigaluh Kulonprogo. Jurnal Pertanian Agros, 18(2), 201-208. Retrieved from http://e-journal.janabadra.ac.id/index.php/JA/ article/view/96

Shintiavira, H., Sulistyaningsih, E., Purwantoro, A., \& Wulandari, R. A. (2019). Morphological and physiological characteristic of three varieties of cut chrysanthemum (Chrysanthemum morifolium R.) cultivated on different altitude in Indonesia. Proceeding International Symposia on Horticulture, 264-269. Retrieved from https://scholar .google.co.id/scholar?cluster $=6956207713828$ 409729\&hl=id\&as_sdt=2005\&sciodt $=0,5 \&$ au thuser $=3$

Simbolon, S. D., Nasution, Z., Rauf, A., \& Delvian. (2017). Sistem pertanian berkelanjutan pada lahan dataran tinggi di kawasan hulu DAS Deli Sumatera Utara. Jurnal Serambi Engineering, 1(2), 85-92. Retrieved from http://ojs.serambimekkah. ac.id/jse/article/view/504

Sumitomo, K., Narumi, T., Satoh, S., \& Hisamatsu, T. (2008). Involvement of the ethylene response pathway in dormancy induction in chrysanthemum. Journal of Experimental Botany, 59(15), 4075-4082. https://doi.org/10.1093/jxb/ern247

Supriyanto, \& Purnama, A. (2015). Pemanfaatan 
pupuk organik granulair dari limbah destilasi etanol sorgum untuk pembibitan leda (Eucalyptus deglupta) pada tanah Andosol, Latosol dan Podzolik. Jurnal Silvikultur Tropika, 6(3), 160-171. Retrieved from https://journal.ipb.ac.id/index.php/jsilvik/artic le/view/11260

Sutapradja, H. (2008). Pertumbuhan dan hasil tanaman tomat kultivar Intan dan Mutiara pada berbagai jenis tanah. Jurnal Hortikultura, 18(2), 160-164. Retrieved from http://ejurnal .litbang.pertanian.go.id/index.php/jhort/article /view/817

Sutrisno, N., \& Heryani, N. (2013). Land and water conservation technology for controlling agricultural land degradation on sloping area. Jurnal Penelitian dan Pengambangan Pertanian, 32(3), 30931. Retrieved from https://core.ac.uk/download/ pdf/300046168.pdf

Tracy, S. R., Black, C. R., Roberts, J. A., \& Mooney, S. J. (2013). Exploring the interacting effect of soil texture and bulk density on root system development in tomato (Solanum lycopersicum L.). Environmental and Experimental Botany, 91, 38-47. https:// doi.org/10.1016/j.envexpbot.2013.03.003

van der Ploeg, A., Kularathne, R. J. K. N., Carvalho, S. M. P., \& Heuvelink, E. (2007). Variation between cut chrysanthemum cultivars in response to suboptimal temperature. Journal of the American Society for Horticultural Science, 132(1), 52-59. https://doi.org/10.21273/jashs.132.1.52

Viyachaia, T., Abdullaha, T. L., Hassana, S. A., Kamarulzamanb, N. H., \& Yusofc, W. A. W. (2015). Development of cut chrysanthemum production in two soillesss systems. Agriculture and Agricultural Science Procedia, 5, 115-121. https://doi.org/10.1016/ j.aaspro.2015.08.016

Wasito, A., \& Marwoto, B. (2003). Evaluasi daya hasil dan adaptasi klon- klon harapan krisan. Jurnal Hortikultura, 13(4), 236-243. Retrieved from http://ejurnal.litbang.pertanian .go.id/index.php/jhort/article/view/1201

Wijayani, A., \& Amiaji, E. (2014). Perbaikan teknik budidaya bunga krisan pasca erupsi merapi di Hargobinangun, Pakem, Sleman untuk peningkatan kualitas bunga. Jurnal Hasil Penelitian Kabupaten Sleman, 1(1), 2540. Retrieved from https://scholar.google. co.id/scholar?cluster=9414095419499460289 \&hl=id\&as_sdt=2005

Zhao, D., \& Tao, J. (2015). Recent advances on the development and regulation of flower color in ornamental plants. Frontiers in Plant Science, 6, 261. https://doi.org/10.3389/fpls. 2015.00261 